\title{
Immunoinformatics Approach for Designing Multiple Epitope-Based Vaccine against Human Metapneumovirus Utilizing its Fusion Protein.
}

Ibtihal A Ahmed ( $\sim$ halaabdalla65@gmail.com )

Ibn Sina University https://orcid.org/0000-0003-3515-3595

Mosab Y Alnour

Omdurman Islamic University

Nafisa M Eisa

Ibn Sina University

Esameldeen A Adam

University of South Africa

Faiza A Omer

Applied Science University

Maali A Osman

University of Khartoum

Sahar O Albagi

Africa City of Techenology

Mohammed A Hassan

Center for Human Genetics and Laboratory Diagnostics

Methodology article

Keywords: Metapneumovirus, fusion protein, Peptides Vaccine, Immunoinformatics, Docking

Posted Date: September 28th, 2020

DOl: https://doi.org/10.21203/rs.3.rs-75441/v1

License: (a) This work is licensed under a Creative Commons Attribution 4.0 International License.

Read Full License 


\section{Abstract}

\section{Background}

Human Metapneumovirus is a major cause of acute respiratory infections especially in children besides it's responsible for substantial hospitalizations associated with significant morbidity and treatment cost. Hence vaccination is required. Consequently, we aim to predict effective, safe, and universal epitopebased peptides vaccine against the HMPV using its Fusion Protein via the Immunoinformatics approach since there are no licensed vaccines or antiviral treatments yet.

To achieve this goal, various Immunoinformatics databases and web servers, including, the Immune Epitope Database used the Allergen FP v.1.0, and ToxinPred web servers as well as Phyre2 web portal for the modeling of peptide 3D structure and molecular docking study on Cresset Flare software.

\section{Result}

According to the results, the peptide GSTVYYPN was the best predicted B-cells epitopes. Moreover, the peptide VIYMVQLPI with population coverage $48.27 \%$ in class(C) I, $35.12 \%$ in (C)II, and the peptides LIGVYGSSV with $44.03 \%$ in C II, YTNVFTLEV with $61.92 \%$ in class I were the best-predicted T-cells epitopes that will interact effectively with the $\mathrm{MHC}$ I and MHC II molecules respectively.

\section{Conclusions}

We recommend the use of them, the highest coverage, and the best -combined allele's bindings of immunogenic multiple peptide vaccines. Also, experimental studies recommend validating the results.

\section{Background}

Human metapneumovirus is one of the leading causes of upper and lower respiratory tract infections in human [1-8]. It is a single negative-stranded RNA virus that belongs to the paramyxoviridae family, pneumovirinae subfamily, metapneumovirus genus [1, 7, 9-12]. It is composed of 13000 nucleotides [12], eight genes and, nine proteins, namely: matrix protein, fusion protein, nucleoprotein, phosphoprotein, small hydrophobic protein, attachment protein, transcription elongation factor, RNA synthesis regulatory factor, and RNA dependent RNA polymerase [1, 11-14]. Minor hydrophobic protein, attachment protein, and fusion proteins are glycoproteins that are present on the virion surface $[1,15-18]$. Both attachment and fusion glycoproteins are required for the human metapneumovirus to enter the host cell as these proteins enable the attachment and fusion of the virus to the host cells, respectively, and subsequently causing the infection [15-18]. There are four clades of human metapneumovirus genes: A1, A2, B1, B2 [1, 19-23]. Fusion proteins are immunogenic and highly conserved among these different subtypes of human metapneumovirus [24]. The infection caused by human metapneumovirus affects all ages, but it could be severe and fatal in infants, elderly and immunocompromised individuals [5, 7, 12, 25, 31-33]. It also can worsen the condition of asthmatic patients [12,31-34] and patients with chronic obstructive 
pulmonary disease, and it may lead to bronchitis or pneumonia $[1,29,35,36,37]$ in elderly patients and children. It is responsible for 5 to $15 \%$ hospitalization of children with acute respiratory tract infection [10, 26 ] and $20 \%$ of deaths in 2000 , with the majority of deaths occurring in sub -Saharan Africa and south of Asia $[1,27]$. The infection was transmitted by direct or close contact with infected patients [30, 35]. Although many vaccines and treatments are under investigation, there are no licensed vaccines or antiviral cures against human metapneumovirus yet [9]. The study aims to use in silico approach to determine antigenic peptides from all strains of human metapneumovirus glycoprotein that could be used for peptide-based vaccine design against human metapneumovirus using immunoinformatic tools that are available online. This study is unique because $B$ cells and $T$ cells epitopes are predicted from human metapneumovirus fusion glycoprotein only, which is highly conserved among different subtypes of human metapneumovirus [24], immunogenic [28] and needed for the first step of virus-cell binding interaction [15-18].

\section{Results}

The predicted B-cells epitopes and their Emini and antigenicity in Table 1 showed the peptide GSTVYYPN was the best peptide, Moreover, the peptide VIYMVQLPI with population coverage $48.27 \%$ in class(C) I, $35.12 \%$ in (C)II, and the peptides LIGVYGSSV with $44.03 \%$ in C II, YTNVFTLEV with $61.92 \%$ in class I were the best-predicted T-cells epitopes that will interact effectively with the $\mathrm{MHC}$ I and $\mathrm{MHC}$ II molecules respectively see table (4)

Table1: Predicited B cell epitope with their eimini and antigenicity score 


\begin{tabular}{|llllll|}
\hline Peptide & Start & End & Length & Emini Score & Antigenicity Score \\
& & & & & \\
\hline YLEESCSTITE & & & & & \\
\hline GDVENLTC & 53 & 33 & 11 & 0.868 & 1.034 \\
\hline DGPSLIK & 62 & 8 & 0.391 & 1.04 \\
\hline QLAREEQIENPRQS & 88 & 101 & 14 & 9.75 & 0.976 \\
\hline AAVT & 116 & 119 & 4 & 0.455 & 1.105 \\
\hline TNEAVSTLGN & 144 & 153 & 10 & 0.883 & 0.98 \\
\hline KCDI & 181 & 184 & 4 & 0.523 & 1.09 \\
\hline QFSDNAGITPA & 206 & 216 & 11 & 0.785 & 0.99 \\
\hline AAPSCS & 288 & 293 & 6 & 0.414 & 1.105 \\
\hline QGWYC & 307 & 311 & 5 & 0.688 & 1.071 \\
\hline GSTVYYPN & 315 & 322 & 8 & 1.557 & 1.042 \\
\hline KDCETRGDHVF & 324 & 334 & 11 & 1.166 & 1.015 \\
\hline AAGINVAEQS & 338 & 347 & 10 & 0.396 & 1.026 \\
\hline ECNIN & 349 & 353 & 5 & 0.564 & 0.993 \\
\hline TNYPCKV & 357 & 363 & 7 & 0.992 & 1.091 \\
\hline TGRHP & 365 & 369 & 6 & 1.974 & 0.965 \\
\hline SYITNQDADTVTIDN & 408 & 422 & 15 & 1.925 & 0.988 \\
\hline SKVEGEQHVI & 428 & 437 & 10 & 0.836 & 1.056 \\
\hline SFDP & 445 & 448 & 4 & 1.248 & 1.008 \\
\hline FPEDQFNV & 451 & 458 & 8 & 1.245 & 1.017 \\
\hline IENSQALV & 478 & 8 & 0.503 & 1.063 \\
\hline SAEKGN & & & & 2.031 & 0.918 \\
\hline
\end{tabular}

Table 2: The predicted T-cell epitopes that interact with $\mathrm{MHCl}$ alleles with their percentile rank and IC50 


\begin{tabular}{|c|c|c|c|c|c|}
\hline Percentile & Ic50 & Allele & End & Start & Peptide \\
\hline 0.6 & 285.95 & HLA-B*40:02 & 28 & 20 & KESYLEESC \\
\hline 0.17 & 93.0 & HLA-C*14:20 & 30 & 22 & SYLEESCST \\
\hline 0.48 & 44.36 & HLA-A*02:01 & 31 & 23 & YLEESCSTI \\
\hline 0.78 & 79.74 & HLA-A*02:06 & & & \\
\hline 0.68 & 421.61 & HLA-C*03:03 & & & \\
\hline 0.2 & 428.87 & HLA-C*05:01 & & & \\
\hline 0.1 & 40.13 & HLA-C*12:30 & & & \\
\hline 0.37 & 262.58 & HLA-C*14:02 & & & \\
\hline 1.9 & 226.09 & HLA-A*02:01 & 45 & 37 & SVLRTGWYT \\
\hline 1.6 & 415.33 & HLA-B*27:05 & 47 & 39 & LRTGWYTNV \\
\hline 0.11 & 365.35 & HLA-C*07:01 & & & \\
\hline 0.36 & 203.72 & HLA-A*24:02 & 48 & 40 & RTGWYTNVF \\
\hline 0.9 & 243.06 & HLA-A*30:02 & & & \\
\hline 0.02 & 6.61 & HLA-A*32:01 & & & \\
\hline 0.78 & 171.06 & HLA-B*15:01 & & & \\
\hline 0.22 & 47.72 & HLA-B*58:01 & & & \\
\hline 0.23 & 436.9 & HLA-C*15:02 & & & \\
\hline 0.17 & 46.75 & HLA-A*23:01 & 50 & 42 & GWYTNVFTL \\
\hline 0.3 & 171.89 & HLA-A*24:02 & & & \\
\hline 0.05 & 209.73 & HLA-C*07:02 & & & \\
\hline 0.23 & 138.87 & HLA-C*14:02 & & & \\
\hline 0.17 & 63.41 & HLA-A*01:01 & 52 & 44 & YTNVFTLEV \\
\hline 0.43 & 39.42 & HLA-A*02:01 & & & \\
\hline 0.55 & 49.99 & HLA-A*02:06 & & & \\
\hline 0.15 & 14.51 & HLA-A*68:02 & & & \\
\hline 0.2 & 111.42 & HLA-C*12:03 & & & \\
\hline 0.01 & 16.47 & HLA-C*15:02 & & & \\
\hline
\end{tabular}




\begin{tabular}{|c|c|c|c|c|c|}
\hline 0.09 & 25.8 & HLA-B*40:01 & 58 & 50 & LEVGDVENL \\
\hline 0.85 & 431.91 & HLA-B*40:02 & & & \\
\hline 0.28 & 27.18 & HLA-B*07:02 & 71 & 63 & GPSLIKTEL \\
\hline 0.75 & 364.35 & HLA-A*30:01 & 81 & 73 & LTKSALREL \\
\hline 0.15 & 102.67 & HLA-B*44:02 & 103 & 95 & IENPRQSRF \\
\hline 0.01 & 4.42 & HLA-B*07:02 & 105 & 97 & NPRQSRFVL \\
\hline 0.19 & 72.33 & HLA-B*07:02 & & & \\
\hline 0.68 & 68.53 & HLA-A*02:06 & 107 & 99 & RQSRFVLGA \\
\hline 0.87 & 478.32 & HLA-A*30:01 & & & \\
\hline 1.7 & 479.78 & HLA-B*27:05 & & & \\
\hline 0.14 & 77.11 & HLA-C*14:02 & 110 & 102 & RFVLGAIAL \\
\hline 1.9 & 279.92 & HLA-A*02:06 & 111 & 103 & FVLGAIALG \\
\hline 0.58 & 54.08 & HLA-A*02:01 & 112 & 104 & VLGAIALGV \\
\hline 1.8 & 261.15 & HLA-A*02:06 & & & \\
\hline 1.9 & 302.3 & HLA-A*02:06 & 134 & 126 & KTIRLESEV \\
\hline 0.04 & 58.71 & HLA-C*15:02 & & & \\
\hline 1.2 & 128.79 & HLA-A*02:06 & 155 & 147 & AVSTLGNGV \\
\hline 0.99 & 219.15 & HLA-A*68:02 & & & \\
\hline 2.4 & 439.34 & HLA-A*02:06 & 157 & 149 & STLGNGVRV \\
\hline 0.84 & 156.59 & HLA-A*68:02 & & & \\
\hline 0.58 & 241.0 & HLA-A*30:01 & 162 & 154 & GVRVLATAV \\
\hline 1.9 & 226.09 & HLA-A*02:01 & 165 & 157 & VLATAVREL \\
\hline 1.6 & 216.61 & HLA-A*02:06 & 196 & 188 & KMAVSFSQF \\
\hline 0.78 & 371.42 & HLA-A*23:01 & & & \\
\hline 0.69 & 458.54 & HLA-A*24:02 & & & \\
\hline 0.26 & 237.52 & HLA-A*32:01 & & & \\
\hline 0.05 & 11.33 & HLA-B*15:01 & & & \\
\hline 0.34 & 81.96 & HLA-B*58:01 & & & \\
\hline 0.55 & 263.06 & HLA-B*35:01 & 197 & 189 & MAVSFSQFN \\
\hline 1.5 & 370.18 & HLA-A*03:01 & 198 & 190 & AVSFSQFNR \\
\hline
\end{tabular}




\begin{tabular}{|c|c|c|c|c|c|}
\hline 0.13 & 22.16 & HLA-A*11:01 & & & \\
\hline 0.17 & 14.32 & HLA-A*31:01 & & & \\
\hline 0.11 & 15.98 & HLA-A*68:01 & & & \\
\hline 0.69 & 102.27 & HLA-A*11:01 & 199 & 191 & VSFSQFNRR \\
\hline 0.16 & 13.62 & HLA-A*31:01 & & & \\
\hline 0.72 & 95.2 & HLA-A*68:01 & & & \\
\hline 0.61 & 393.3 & HLA-A*24:02 & 200 & 192 & SFSQFNRRF \\
\hline 0.06 & 137.33 & HLA-C*06:02 & 201 & 193 & FSQFNRRFL \\
\hline 0.13 & 60.38 & HLA-C*12:03 & & & \\
\hline 0.08 & 34.12 & HLA-C*12:03 & 204 & 196 & FNRRFLNVV \\
\hline 0.27 & 72.0 & HLA-B*27:05 & 206 & 198 & RRFLNVVRQ \\
\hline 0.15 & 38.7 & HLA-A*23:01 & 207 & 199 & RFLNVVRQF \\
\hline 0.16 & 106.71 & HLA-A*24:02 & & & \\
\hline 0.25 & 215.15 & HLA-A*32:01 & & & \\
\hline 0.56 & 490.25 & HLA-C*14:02 & & & \\
\hline 0.59 & 253.25 & HLA-A*30:01 & 211 & 203 & VVRQFSDNA \\
\hline 0.58 & 54.22 & HLA-A*02:06 & 214 & 206 & RQFSDNAGI \\
\hline 1.3 & 301.73 & HLA-B*15:01 & & & \\
\hline 1.5 & 407.1 & HLA-B*27:05 & & & \\
\hline 0.35 & 111.38 & HLA-C*05:01 & 215 & 207 & FSDNAGITP \\
\hline 1.6 & 416.65 & HLA-A*68:02 & 217 & 209 & DNAGITPAI \\
\hline 0.35 & 127.59 & HLA-C*03:03 & 219 & 211 & AGITPAISL \\
\hline 0.52 & 450.44 & HLA-C*14:02 & 221 & 213 & ITPAISLDL \\
\hline 0.27 & 85.95 & HLA-B*35:01 & 222 & 214 & TPAISLDLM \\
\hline 1.7 & 166.24 & HLA-A*31:01 & 248 & 240 & QIKLMLENR \\
\hline 1.7 & 311.74 & HLA-A*68:01 & & & \\
\hline 1.3 & 465.82 & HLA-B*07:02 & 250 & 242 & KLMLENRAM \\
\hline 0.99 & 251.82 & HLA-B*15:01 & & & \\
\hline 0.07 & 40.02 & HLA-C*14:02 & & & \\
\hline 0.38 & 33.58 & HLA-A*02:01 & 251 & 243 & LMLENRAMV \\
\hline
\end{tabular}




\begin{tabular}{|c|c|c|c|c|c|}
\hline 0.23 & 17.43 & HLA-A*02:06 & & & \\
\hline 0.49 & 414.98 & HLA-C*12:03 & & & \\
\hline 1.8 & 192.75 & HLA-A*31:01 & 252 & 244 & MLENRAMVR \\
\hline 1.2 & 167.51 & HLA-A*68:01 & & & \\
\hline 0.93 & 326.77 & HLA-B*07:02 & 256 & 248 & RAMVRRKGF \\
\hline 0.11 & 41.4 & HLA-B*08:01 & & & \\
\hline 0.58 & 185.15 & HLA-B*57:01 & & & \\
\hline 0.14 & 28.29 & HLA-A*30:01 & 258 & 250 & MVRRKGFGI \\
\hline 0.31 & 129.72 & HLA-B*08:01 & & & \\
\hline 0.6 & 268.16 & HLA-A*30:01 & 260 & 252 & RRKGFGILI \\
\hline 0.08 & 25.05 & HLA-B*27:05 & & & \\
\hline 0.74 & 74.41 & HLA-A*02:06 & 262 & 254 & KGFGILIGV \\
\hline 1.2 & 307.12 & HLA-A*29:02 & 263 & 255 & GFGILIGVY \\
\hline 0.82 & 261.58 & HLA-A*30:02 & & & \\
\hline 0.44 & 105.26 & HLA-A*03:01 & 269 & 261 & GVYGSSVIY \\
\hline 0.7 & 102.81 & HLA-A*11:01 & & & \\
\hline 0.17 & 22.0 & HLA-A*29:02 & & & \\
\hline 0.31 & 87.83 & HLA-A*30:02 & & & \\
\hline 0.78 & 167.62 & HLA-B*15:01 & & & \\
\hline 0.65 & 350.49 & HLA-B*35:01 & & & \\
\hline 0.08 & 44.78 & HLA-C*14:02 & 270 & 262 & VYGSSVIYM \\
\hline 2.7 & 427.15 & HLA-A*02:01 & 271 & 263 & YGSSVIYMV \\
\hline 2.1 & 359.13 & $H L A-A * 02: 06$ & & & \\
\hline 0.38 & 46.96 & HLA-A*68:02 & & & \\
\hline 0.2 & 115.96 & HLA-C*12:03 & & & \\
\hline 1.3 & 137.15 & HLA-A*02:01 & 275 & 267 & VIYMVQLPI \\
\hline 1.7 & 231.88 & $H L A-A * 02: 06$ & & & \\
\hline 0.11 & 79.87 & HLA-A*32:01 & & & \\
\hline 0.28 & 182.9 & HLA-C*14:02 & & & \\
\hline 0.23 & 456.3 & HLA-C*15:02 & & & \\
\hline
\end{tabular}




\begin{tabular}{|c|c|c|c|c|c|}
\hline 0.05 & 15.34 & $H L: 0 A-A * 23: 01$ & 276 & 268 & IYMVQLPIF \\
\hline 0.02 & 15.62 & HLA-A*24:02 & & & \\
\hline 0.16 & 88.99 & HLA-C*14:02 & & & \\
\hline 1.3 & 133.11 & HLA-A*02:01 & 278 & 270 & MVQLPIFGV \\
\hline 0.25 & 20.62 & HLA-A*02:06 & & & \\
\hline 0.07 & 7.67 & HLA-A*68:02 & & & \\
\hline 0.21 & 16.39 & HLA-A*02:06 & 279 & 271 & VQLPIFGVI \\
\hline 1.7 & 472.81 & HLA-B*15:01 & & & \\
\hline 0.75 & 296.91 & HLA-B*58:01 & 309 & 301 & CLLREDQGW \\
\hline 1.4 & 360.17 & HLA-A*30:02 & 310 & 302 & LLREDQGWY \\
\hline 1.3 & 314.49 & HLA-B*15:01 & & & \\
\hline 0.49 & 278.92 & HLA-B*18:01 & 334 & 326 & CETRGDHVF \\
\hline 0.26 & 80.04 & HLA-B*35:01 & 340 & 332 & HVFCDTAAG \\
\hline 0.4 & 51.76 & HLA-A*68:02 & 344 & 336 & DTAAGINVA \\
\hline 1.8 & 264.17 & HLA-A*02:06 & 370 & 362 & KVSTGRHPI \\
\hline 0.3 & 84.76 & HLA-A*30:01 & & & \\
\hline 0.21 & 156.17 & HLA-A*32:01 & & & \\
\hline 0.59 & 171.75 & HLA-B*07:02 & & & \\
\hline 0.32 & 483.17 & HLA-B*39:01 & 375 & 367 & RHPISMVAL \\
\hline 0.04 & 385.56 & $\mathrm{HLA}-\mathrm{B} * 48: 01$ & & & \\
\hline 0.23 & 146.04 & HLA-C*14:02 & & & \\
\hline 0.49 & 216.61 & HLA-B*35:01 & 376 & 368 & HPISMVALS \\
\hline 0.58 & 53.87 & HLA-A*02:06 & 378 & 370 & ISMVALSPL \\
\hline 0.91 & 220.25 & HLA-B*15:01 & & & \\
\hline 0.62 & 209.97 & HLA-B*58:01 & & & \\
\hline 0.09 & 165.86 & HLA-C*15:02 & & & \\
\hline 0.14 & 54.37 & HLA-A*68:02 & 380 & 372 & MVALSPLGA \\
\hline 2.2 & 374.62 & HLA-A*02:06 & 381 & 373 & VALSPLGAL \\
\hline 1.2 & 394.88 & HLA-B*07:02 & & & \\
\hline 0.06 & 9.92 & HLA-C*03:03 & & & \\
\hline
\end{tabular}




\begin{tabular}{|c|c|c|c|c|c|}
\hline 0.39 & 34.86 & HLA-A*02:01 & 382 & 374 & ALSPLGALV \\
\hline 0.53 & 48.2 & HLA-A*02:06 & & & \\
\hline 1.3 & 468.47 & HLA-B*07:02 & 384 & 376 & SPLGALVAC \\
\hline 0.64 & $64: 16$ & HLA-A*02:06 & 388 & 380 & ALVACYKGV \\
\hline 0.13 & 235.57 & HLA-C*15:02 & 418 & 410 & ITNQDADTV \\
\hline 0.69 & 69.02 & $\mathrm{HLA}^{-A^{*} 02: 06}$ & 420 & 412 & NQDADTVTI \\
\hline 0.06 & 37.05 & HLA-B*39:01 & & & \\
\hline 0.07 & 7.73 & HLA-A*68:02 & 424 & 416 & DTVTIDNTV \\
\hline 1.4 & 388.21 & HLA-A*30:02 & 425 & 417 & TVTIDNTVY \\
\hline 0.3 & 103.47 & HLA-B*35:01 & & & \\
\hline 2.7 & 422.96 & HLA-A*02:01 & 427 & 419 & TIDNTVYQL \\
\hline 2.5 & 458.02 & HLA-A*02:06 & & & \\
\hline 0.18 & 363.75 & HLA-B*05:01 & & & \\
\hline 0.17 & 17.37 & HLA-A*68:02 & 430 & 422 & NTVYQLSKV \\
\hline 2.2 & 362.99 & HLA-A*02:06 & 433 & 425 & YQLSKVEGE \\
\hline 0.23 & 66.27 & HLA-B*35:01 & 459 & 451 & FPEDQFNVA \\
\hline 014 & 52.47 & HLA-B*40:01 & 460 & 452 & PEDQFNVAL \\
\hline 1.4 & 345.58 & HLA-B*15.01 & 464 & 456 & FNVALDQVF \\
\hline 0.35 & 133.51 & HLA-B*35:01 & & & \\
\hline
\end{tabular}

Table 4: the predicted $\mathrm{MHC1}, \mathrm{MHC11}$, and the $\mathrm{MHC}$ combined peptide are having the highest percent in population coverage

\begin{tabular}{|llllll|}
\hline $\begin{array}{l}\text { MHCI } \\
\text { Peptides }\end{array}$ & $\begin{array}{l}\text { The } \\
\text { coverage }\end{array}$ & $\begin{array}{l}\text { MHC II } \\
\text { peptides }\end{array}$ & $\begin{array}{l}\text { The } \\
\text { coverage }\end{array}$ & $\begin{array}{l}\text { MHC } \\
\text { combined }\end{array}$ & $\begin{array}{l}\text { The } \\
\text { coverage }\end{array}$ \\
\hline YTNVFTLEV & IKLMLENRA & $48.63 \%$ & YTNVFTLEV & $61.92 \%$ \\
\hline YLEESCSTI & $57.06 \%$ & LIGVYGSSV & $44.03 \%$ & YLEESCSTI & $57.06 \%$ \\
\hline VIYMVQLPI & $48.27 \%$ & VIYMVQLPI & $35.12 \%$ & IKLMLENRA & $48.63 \%$ \\
\hline Epitope set & $99.52 \%$ & & $81.94 \%$ & & $99.91 \%$ \\
\hline
\end{tabular}


Table 5: The predicted Allergicity, toxicity, and the molecular docking scores of the predicted peptides with MHC IA, MHC IB, and MHC II molecules.

\begin{tabular}{|c|c|c|c|c|c|}
\hline $\begin{array}{l}\text { The } \\
\text { Peptides }\end{array}$ & $\begin{array}{l}\text { MHC IA Docking } \\
\text { score (6AM5) }\end{array}$ & $\begin{array}{l}\text { MHC IB Docking } \\
\text { score (5TXS) }\end{array}$ & $\begin{array}{l}\text { MHC II Docking } \\
\text { score (5NI9) }\end{array}$ & $\begin{array}{l}\text { The } \\
\text { Allergenicity }\end{array}$ & $\begin{array}{l}\text { The } \\
\text { Toxicity }\end{array}$ \\
\hline \multirow[t]{2}{*}{ YTNVFTLEV } & & Not docked & - & Non-allergen & $\begin{array}{l}\text { Non- } \\
\text { Toxin }\end{array}$ \\
\hline & Not docked & & & & \\
\hline YLEESCSTI & Not docked & Not docked & - & $\begin{array}{l}\text { Probable } \\
\text { allergen }\end{array}$ & $\begin{array}{l}\text { Non- } \\
\text { Toxin }\end{array}$ \\
\hline VIYMVQLPI & -4.893 & -4.235 & - & $\begin{array}{l}\text { Probable } \\
\text { allergen }\end{array}$ & $\begin{array}{l}\text { Non- } \\
\text { Toxin }\end{array}$ \\
\hline IKLMLENRA & - & - & Not docked & $\begin{array}{l}\text { Probable } \\
\text { allergen }\end{array}$ & $\begin{array}{l}\text { Non- } \\
\text { Toxin }\end{array}$ \\
\hline LIGVYGSSV & - & - & -6.244 & Non-allergen & $\begin{array}{l}\text { Non- } \\
\text { Toxin }\end{array}$ \\
\hline VIYMVQLPI & - & - & -6.556 & $\begin{array}{l}\text { Probable } \\
\text { allergen }\end{array}$ & $\begin{array}{l}\text { Non- } \\
\text { Toxin }\end{array}$ \\
\hline YTNVFTLEV & Not docked & Not docked & Not docked & Non-allergen & $\begin{array}{l}\text { Non- } \\
\text { Toxin }\end{array}$ \\
\hline YLEESCSTI & Not docked & Not docked & Not docked & $\begin{array}{l}\text { Probable } \\
\text { allergen }\end{array}$ & $\begin{array}{l}\text { Non- } \\
\text { Toxin }\end{array}$ \\
\hline IKLMLENRA & Not docked & Not docked & Not docked & $\begin{array}{l}\text { Probable } \\
\text { allergen }\end{array}$ & $\begin{array}{l}\text { Non- } \\
\text { Toxin }\end{array}$ \\
\hline
\end{tabular}

\section{Discussion}

We highlighted our most promising antigenic peptide of the B-cells epitopes GSTVYYPN (Table 1). And for the T-cells epitopes the best MHC I Peptides are YTNVFTLEV, YLEESCSTI and VIYMVQLPI (Table 2).

Moreover, the best MHC II peptides are IKLMLENRA, LIGVYGSSV and VIYMVQLPI (Table 3) the epitopebased peptide vaccines that include the B-cells and T-cells epitopes are well antigenic [38] and could be produced simply [39]. comparing our study with other studies predicted immunogenic epitope for the Design of Epitope-Based HMPV Vaccines (Rock et al., 2011) in terms of agreement MHC class 1 binding with 3 conventional alleles HLA-A*01:01, HLA-A*02:01, and with HLA-B*07:02 alleles using (BIMAS) bioinformatics analysis tool [40] Our finding for MHC 1 Peptides binds 17 alleles HLA-A*01:01, HLA$A^{\star}$ 02:01, HLA-A*02:06, HLA-A*68:02, HLA-C*12:03, and HLAC*15:02,HLA-A*02:01, HLA-A*02:06, HLAC*03:03, HLA-C*05:01, HLA-C*12:30 and HLA-C*14:02, HLA-A*02:01, HLA-A*02:06, HLA-A*32:01, HLA-C*14:02, and HLA-C*15:02 (Table 2). 
HLADRB1*01:01, HLA-DRB4*01:01, HLA-DRB1*04:01, HLA-DRB1*11:01, HLADRB1*15:01, HLADRB1*04:05, HLA-DRB5*01:01 and HLA-DRB1*09:01,

(Table 3).

The predicted peptides for $\mathrm{MHC}$ I and $\mathrm{MHC}$ II have a highest population coverage.For $\mathrm{MHC} \mathrm{I,} \mathrm{MHC} \mathrm{II}$ peptides the percentage were $99.52 \%, 81.94 \%$, respectively and for MHC combined was $99.91 \%$ (Table $4)$.

\section{Conclusion}

The study led to the prediction of effective and safe epitope-based peptides vaccine against the HMPV using its Fusion Protein via the Immunoinformatics approach. The peptide GSTVYYPN was the best predicted B-cells epitopes. Moreover, the peptide VIYMVQLPI and the peptides LIGVYGSSV, YTNVFTLEV were the best-predicted T-cells epitopes that will interact effectively with the $\mathrm{MHC}$ I and $\mathrm{MHC}$ II molecules, respectively. Consequently, we recommend the use of them as combined multiple peptide vaccines. Also, experimental studies recommended to validate the results.

\section{Methods}

\section{Retrieval of the targeted sequences}

A total of 182 Human Metapneumovirus Fusion Protein sequences were obtained from the NCBI database [41] as the FASTA format in August 2018. The accession numbers of the obtained sequences with the area and date of the collection were listed in Table 6. 
Table 6

the retrieved Human Metapneumovirus Fusion Protein sequences with their Accession number, Date and area of Collection

\begin{tabular}{|lll|}
\hline & & \\
Accession number & Date of collection & country \\
\hline & & \\
\hline YP_012608 & 2004 & USA \\
\hline BBB35016 & 2015 & japan \\
\hline BBB35015 & 2015 & Japan \\
\hline BBB35014 & $20 / 3 / 2015$ & Japan \\
\hline BBB35013 & $2015-03-16 "$ & Japan \\
\hline BBB35012 & $2015-03-16 "$ & Japan \\
\hline BBB35011 & $2015-02-27$ & Japan \\
\hline BBB35010 & $2015-02-21$ & Japan \\
\hline BBB35009 & $2015-02-21$ & Japan \\
\hline BBB35008 & $2015-02-21 "$ & Japan \\
\hline BBB35007.1 & $2014-04-12$ & Japan \\
\hline BBB35006.1 & $2014-04-13 "$ & Japan \\
\hline BBB35005.1 & $2014-04-05$ & Japan \\
\hline BBB35004.1 & $2013-07-08 "$ & Japan \\
\hline BBB35003.1 & $2013-06-22 "$ & Japan \\
\hline BBB35002.1 & $2013-06-24$ & Japan \\
\hline BBB35001.1 & $2013-06-24$ & Japan \\
\hline BBB35000.1 & $2013-04-30$ & Japan \\
\hline BBB34999.1 & $2013-04-16$ & Japan \\
\hline BBB34998.1 & $2013-04-08 "$ & Japan \\
\hline BBB34997.1 & $2013-03-25$ & Japan \\
\hline BBB34996.1 & $2013-01-21$ & Japan \\
\hline BBB34995.1 & Japan \\
\hline BBB34994.1 & Japan \\
\hline
\end{tabular}

Page $13 / 26$ 


\begin{tabular}{|lll|}
\hline Accession number & Date of collection & country \\
\hline BBB34992.1 & $2013-06-25$ & Japan \\
\hline BBB34991.1 & $2013-06-24$ & Japan \\
\hline BBB34990.1 & $2013-06-22$ & Japan \\
\hline ANW38002.1 & 2011 & Croatia \\
\hline ANW38000.1 & 2013 & Croatia \\
\hline ANW37997.1 & 2012 & Croatia \\
\hline ANW37998.1 & 2012 & Croatia" \\
\hline ANW37996.1 & 2012 & Croatia \\
\hline ANW37993.1 & 2011 & Croatia" \\
\hline ANW37992.1 & 2011 & Croatia" \\
\hline ANW37991.1 & 2011 & Croatia" \\
\hline ANW37990.1 & 2011 & Croatia \\
\hline ANW37989.1 & 2011 & Croatia \\
\hline All17595.1 & $10-$ Aug-2011 & South Korea \\
\hline
\end{tabular}

\section{Determinant of the conserved regions}

The obtained Sequences subjected to the multiple alignment tests via the CLUSTALW algorithm [42] on BioEdit software [43] version 7.0.9.1 to identify the conserved regions.

\section{B-Cells Epitopes Prediction}

The linear Epitope Prediction tool BepiPred-test on the Immune Epitope Database (IEDB) [44] (figure ).

The epitopes were predicted at a default threshold value of (0.4) from the conserved region in the Human Metapneumovirus Fusion Protein sequences that obtained from the multiple sequences, alignment. The prediction performed using the Markov model [45]. The results listed in Table 1.

\section{The Surface Accessibility Prediction}

The Emini surface accessibility prediction tool [43] on the IEDB [46] used to predict the surface accessibility with a default threshold value for each conserved region (Fig. 9). The results are listed in Table 1. 
The Kolaskar and Tongaonker antigenicity tool on IEDB [47] used for the prediction of the antigenic sites within the Human Metapneumovirus Fusion Protein sequences at a default threshold value of 1.04. The results listed in Table 1, (Fig. 10). For the whole first alignment, sequences see (Fig. 11).

\section{T-Cell Epitopes Prediction}

The prediction of the cytotoxic T-cell epitopes performed by using the Major Histocompatibility Complex class I (MHC I) binding prediction tool on IEDB [48]. The epitopes' length adjusted at 9 . The conserved epitopes that bind with various HLA alleles at score equal or less than 1.0 percentile rank and 500 IC50 selected for further analysis. Moreover, the prediction of T-cell helper epitopes performed by using the Major Histocompatibility Complex class II (MHC II) binding prediction tool of IEDB [49]. The results listed in Table 3.

\section{The Population Coverage Prediction}

The prediction of epitopes binding with various $\mathrm{MHC}$ I and $\mathrm{MHC}$ II alleles that cover the world population was performed by using the population coverage tool on the IEDB [50]. The results are listed in Table 4.

\section{The Peptides Allergicity and Toxicity Prediction}

The AllergenFP v.1.0 [47] web servers used to predict the Allergenicity. Furthermore, ToxinPred web server [48] used to predict the Toxicity. The results listed in Table 5.

\section{The 3D Structure Modeling and Visualization}

The 3D structure of the Human Metapneumovirus Fusion Protein modeled by using the Phyre2 web portal [49] and 3D structure the predicted peptides we modeled by using PEP-FOLD 3.5 web server [50]. The modeled 3D structures visualized by Chimera 1.8 software [51]. The results presented in Figs. 1, 2, and .

\section{The Molecular Docking Study}

The predicted epitopes were docked with $\mathrm{MHC}$ I and MHC II molecules. The Protein Databank [52] was used to obtain the 3D structures of MHC I and MHC II. The 3D structures (PDBIDs:

6AM5, 5TXS, and 5NI9 for MHC IA, MHC IB, and MHC II respectively) were downloaded in PDB format. The. The structures were prepared, minimized for the docking process, and the molecular docking calculation performed by using Cresset Flare software [53]. The results listed in Table 5 and showed in Figs. 4,5,6, and 7 .

\section{Declarations}

\section{Ethics approval and consent to participate}


Not applicable

\section{Consent for publication}

Not applicable

\section{Availability of data and materials}

The datasets generated during and/or analyzed during the current study are available from the corresponding author on reasonable request.

\section{Competing interests}

The authors declare that having no conflict of interest.

\section{Funding}

Authors declare that there's no fund available for this study

\section{Authors' contributions}

All authors contributed in this work as follows:

\section{Acknowledgements}

We acknowledge Africa city of technology teams for their support and help.

\section{References}

1. Swagatika P. Nirmal Kumar Mohakud b, Lindomar Pena c, Subrat Kumar, Human metapneumovirus: review of an important respiratory pathogen. International Journal of Infectious Diseases. 2014;25:45-52.

2. Gabriella Cseke DW, Wright SJ, Tollefson JE, Johnson JE, Crowe, Jr. and John V. Williams, Human Metapneumovirus Fusion Protein Vaccines That Are Immunogenic and Protective in Cotton Rats, JOURNAL OF VIROLOGY, Jan. 2007, pp. 698-707.

3. Cane PA, van den Hoogen BG, Chakrabarti S, Fegan CD, Osterhaus AD. Human metapneumovirus in a hematopoietic stem cell transplant recipient with fatal lower respiratory tract disease. Bone Marrow Transplant. 2003;31:309-10.

4. Landry, and J

Esper F, Martinello RA, Boucher D, Weibel C, Ferguson D. M. L. Landry, and J. S. 
5. Kahn. A 1-year experience with human metapneumovirus in children aged_5 years. J Infect Dis. 2004;189:1388-96.

6. Falsey AR, Erdman D, Anderson LJ, Walsh EE. Human metapneumovirus infections in young and elderly adults. J Infect Dis. 2003;187:785-90.

7. J. M.Pingsterhaus, $\mathrm{K}$ Williams JV, Harris PA, Tollefson SJ, Halburnt-Rush LL. J. M.Pingsterhaus, K.

8. Edwards M, Wright PF, Crowe JE Jr. 2004. Human metapneumovirus and lower respiratory tract disease in otherwise healthy infants and children. N. Engl. J. Med.

9. $350 .: 443-450$.

10. Van den Hoogen BG, de Jong JC, Groen J, Kuiken T, de Groot R, Fouchier RA, Osterhaus AD. A newly discovered human pneumovirus isolated from young children with respiratory tract disease. Nat Med. 2001;7:719-24.

11. Williams JV, Tollefson SJ, Heymann PW, Carper HT, Patrie J, Crowe JE. Human metapneumovirus infection in children hospitalized for wheezing. J Allergy Clin Immunol. 2005;115:1311. - 1312.

12. Zhang Yu. a, b Yongwei Wei,a Xiaodong Zhang,a Hui Cai, a Stefan Niewiesk,a Jianrong Lia, Rational Design of Human Metapneumovirus Live Attenuated Vaccine Candidates by Inhibiting Viral mRNA Cap Methyltransferase, Journal of Virology, 88(19) p. 11411-11429.

13. Li X, LiruGuo MK, Yang XuS,D, Zou M, Liu Y, Lu L. Design, and Evaluation of a Multi-EpitopePeptide of Human Metapneumovirus. Intervirology. 2015;58:403-12. Epub April 21, 2016.

14. Bianchi S, Skiadopoulos MH, Boivin G, Hanson CT. Murphy BR, Collins PL et al.

15. Genetic diversity between human metapneumovirus subgroups. Virology. 2003;315:1-9.

16. Karen A, Herd S, Mahalingam IM Mackay,1 Michael Nissen, Theo P. Sloots, and Robert W. Tindle, Cytotoxic T-Lymphocyte Epitope Vaccination Protects against Human Metapneumovirus Infection and Disease in Micet, JOURNAL OF VIROLOGY, Feb. 2006, p. 2034-2044.

17. Biacchesi S, Skiadopoulos MH, Yang L, Lamirande EW, Tran KC, Murphy BR, Collins PL, Buchholz UJ. Recombinant human metapneumovirus lacking the small hydrophobic $\mathrm{SH}$ and attachment $\mathrm{G}$ glycoprotein: deletion of $\mathrm{G}$ yields a promising vaccine candidate. J Virol. 2004;78:12877,-12887.

18. van den Hoogen BG, Bestebroer TM, Osterhaus AD, Fouchier RA. Analysis of the genomic sequence of a human metapneumovirus. Virology. 2002;295:119-32.

19. The Human

Cox RG, Livesay SB, Johnson M, Ohi MD, Williams JV. 2012. The Human.

20. Metapneumovirus Fusion Protein Mediates. Entry Via an Interaction with RGD-binding Integrins. J Virol.

21. Cseke G, Maginnis MS, Cox RG, Tollefson SJ, Podsiad AB, Wright DW, Dermody TS, Williams JV. Integrin alphavbeta1 promotes Downloaded from http://cvi.asm.org/ on September 6, 2018, by guest 21 infection by human metapneumovirus. Proc Natl Acad Sci U S A. 2009;106:1566-71. 
22. Schowalter RM, Chang A, Robach JG, Buchholz UJ, Dutch RE. Low-pH triggering of human metapneumovirus fusion: essential residues and importance in an entry. J Virol. 2009;83:1511-22.

23. Chang A, Musante C, Buchholz UJ, Dutch RE. Human metapneumovirus (HMPV) binding and infection are mediated by interactions between the HMPV fusion protein and heparan sulfate. J Virol. 2012;86:3230-43.

24. Boivin G, Mackay I, Sloots TP, Madhi S, Freymuth F, Wolf D, Shemer- Avni Y, Ludwick H, Gray GC, LeBlanc E. Global genetic diversity of human metapneumovirus fusion gene. Emerg Infect Dis. 2004;10:1154-7.

25. Van den Hoogen BG, Herfst S, Sprong L, Cane PA, Forleo-Neto E, deSwart RL, Osterhaus AD, Fouchier RA. Antigenic and genetic variability of human metapneumoviruses. Emerg Infect Dis. 2004;10:65866.

26. Yang CF, Wang CK, Tollefson SJ, Piyaratna R, Lintao LD, Chu M, Liem A, Mark M, Spaete RR, Crowe JE Jr, Williams JV. 2009. Genetic diversity and evolution of human metapneumovirus fusion protein over twenty years. Virol J 6:138. Downloaded from http://cvi.asm.org/ on September 6, 2018, by guest 22.

27. Piyaratna R, Tollefson SJ, Williams JV. Genomic analysis of four human metapneumovirus prototypes. Virus Res. 2011;160:200-5.

28. Gaunt ER, Jansen RR, Poovorawan Y, Templeton KE, Toms GL, Simmonds P. Molecular epidemiology and evolution of the human respiratory syncytial virus and human metapneumovirus. PLoS ONE. 2011;6:e17427.

29. Schildgen V, van den Hoogen B, Fouchier R, Tripp RA, Alvarez R, Manoha C, Williams J, Schildgen 0 . Human Metapneumovirus: lessons learned over the first decade. Clin Microbiol Rev. 2011;24:73454.

30. Williams JV, Wang CK, Yang CF, Tollefson SJ, House FS. Heck JM.

31. Chu M, Brown JB, Lintao LD, Quinto JD, Chu D, Spaete RR, Edwards KM, Wright PF, Crowe JE Jr. The role of human metapneumovirus in upper respiratory tract infections in children: a 20-26.year experience. The Journal of infectious diseases. 2006;193:387-95.

32. Li XY, Chen JY, Kong M, Su X, Yi YP, Zou M, et al. Prevalence of human metapneumovirus in hospitalized children with respiratory tract infections in Tianjin, China. Arch Virol. 2009;154:1831-6.

33. Williams BG, Gouws E, Boschi-Pinto C, Bryce J, Dye C. Estimates of worldwide distribution of child deaths from acute respiratory infections. Lancet Infect Dis. 2002;2:25-32.

34. Cox RG, Erickson JJ, Hastings AK, Becker JC, Johnson M, Craven RE, Tollefson SJ, Boyd KL, Williams $\mathrm{JV}$. Human metapneumovirus virus-like particles induce protective $B$ and $T$ cell responses in a mouse model. J Virol. 2014;88:6368-79.

35. Nathalie Bastien S, Normand TTaylorD, Ward, Teresa CT, Peret G, Boivin LJ, Anderson Y, Li. Sequence analysis of the $\mathrm{N}, \mathrm{P}, \mathrm{M}$ and $\mathrm{F}$ genes of Canadian human metapneumovirus strains. Virus Res. 2003;93:51/62. 
36. Haas LE, Thijsen SF, van Elden L, et al. Human metapneumovirus in adults. Viruses. 2013;5(1):87110.

37. Pelletier G, Dery P, Abed Y, Boivin G. 2002. Respiratory tract reinfections by the new human metapneumovirus in an immunocompromised child. Emerg. Infect. Dis.

38. 8.:976-978.

39. Williams JV, Crowe JE Jr, Enriquez R, Minton P, Peebles RS Jr, Hamilton RG, Higgins S, Griffin M, Hartert TV. Human metapneumovirus infection plays an etiologic role in acute asthma exacerbations requiring hospitalization in adults. J Infect Dis. 2005;192:1149-53.

40. Williams JV, Martino R, Rabella N, Otegui M, Parody R, Heck JM, Crowe JE Jr. A prospective study comparing human metapneumovirus with other respiratory viruses in adults with hematologic malignancies and respiratory tract infections. J Infect Dis. 2005;192:1061-5.

41. S. Chiu

Peiris JS, Tang WH, Chan KH, Khong PL, Guan Y, Lau YL. and S. S. Chiu.

42. Children with respiratory. disease associated with metapneumovirus in Hong Kong. Emerg. Infect. Dis. 9:628-633.

43. Nazly Shafagati J, Williams. Human metapneumovirus - what we know now [version 1; referees: 2 approved], F1000Research 2018, 7(F1000 Faculty Rev):135.

44. Howard LM, Edwards KM, Zhu Y, et al.: Clinical Features of Human Metapneumovirus Infection in Ambulatory Children Aged 5-13 Years.

45. J Pediatric Infect Dis Soc. 2017.

46. Matsuda S, Nakamura M, Hirano E, Kiyota N, Omura T, Suzuki Y, et al. Characteristics of human metapneumovirus infection prevailing in hospital wards housing patients with severe disabilities. Jpn J Infect Dis. 2013;66:195-200.

47. Li W, Joshi MD, Singhania S, Ramsey KH, Murthy AK. "Peptide Vaccine: Progress and Challenges," Vaccines, vol. 2, pp. 515-536, 2014.

48. Skwarczynski M, Toth I. "Peptide-based synthetic vaccines," Chemical science, vol. 7, pp. 842-854, 2016.

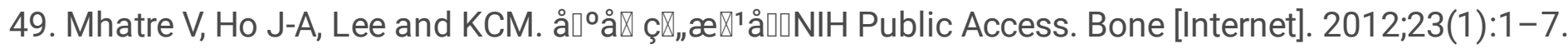
Available from: https://www.ncbi.nlm.nih.gov/pmc/articles/PMC3624763/pdf/nihms412728.pdf.

50. Altschul SF, Gish W, Miller W, Myers EW, Lipman DJ. "Basic local alignment search tool". Journal of molecular biology. 1990;215:403-10.

51. Julie DGH, Thompson D, Toby J, Gibson. "CLUSTAL W: improving the sensitivity of progressive multiple sequence alignment through sequence weighting, position-specific gap penalties, and weight matrix choice". Nucleic Acids Res. 1994;22:4673-80.

52. Hall TA, "BioEdit: a user-friendly biological sequence alignment editor and analysis program for Windows 95/98/NT," Nucleic Acids Symposium Series, vol. 41, pp. 95-98, // 1999. 
53. Vita R, Overton JA, Greenbaum JA, Ponomarenko J, Clark JD, Cantrell JR, et al, "The immune epitope database (IEDB) 3.0" Nucleic acids research, vol. 43, pp. D405-D412, 2015.

54. a. LO, Larsen NM. JE, "Improved method for predicting linear B-cell epitopes" Immunome Res vol. 2, 2006.

55. Emini HJ, Perlow EA DS, and Boger J. "Induction of hepatitis A virus-neutralizing antibody by a virusspecific synthetic peptide. J Virol vol. 1985;55:836-9.

56. Ivan LN, Dimitrov I, Doytchinova, Bangor I, "AllergenFP: allergenicity prediction y descriptor fingerprints," Bioinformatics, vol. 30, pp. 846-851, 2013.

57. Gupta S, Kapoor P, Chaudhary K, Gautam A, Kumar R. C. Open Source Drug Discovery, et al., "Insilico approach for predicting the toxicity of peptides and proteins," PloS one, vol. 8, pp. e73957-e73957, 2013.

58. K. e. al., "The Phyre2 web portal for protein modeling, prediction, and analysis," Nature Protocols, vol. 10, 2015.

59. Alexis Lamiable PT, Rey J, Vavrusa M, Derreumaux P, Tuffery P. "PEP-FOLD3: faster de novo structure prediction for linear peptides in solution and complex " Nucleic Acids Research, vol. 44, pp. W449454, 2016.

60. Pettersen GT, Huang EF, Couch CC, Greenblatt GS, Meng DM, Ferrin EC. TE, "UCSF Chimera-a visualization system for exploratory research and analysis". J Comput Chem. 2004;25:1605-12.

61. Frances TFK, Bernstein C, Graphene JB, Williams, Edger F, Meyer MD Jr, Brice JR, Rodgers. Olga Kennard, Takehiko Shimanouchi, Mitsuo Tasumi, "The protein data bank: A computer-based archival file for macromolecular structure " Eur J Biochem., vol. 80, pp. 319-324, 1977.

62. "A. Molecular Field Cresset ${ }^{\circledR}$ vF, Litlington, Cambridgeshire UK, http://www.cressetgroup.com/flare/; Cheeseright T, Mackey M, Rose S, Vinter. "A. Molecular Field.

63. Extrema as Descriptors of Biological Activity. Definition and Validation.". J Chem Inf Model. 2006;46:665-76.

\section{Tables}

Due to technical limitations, table 3 is only available as a download in the Supplemental Files section.

\section{Figures}




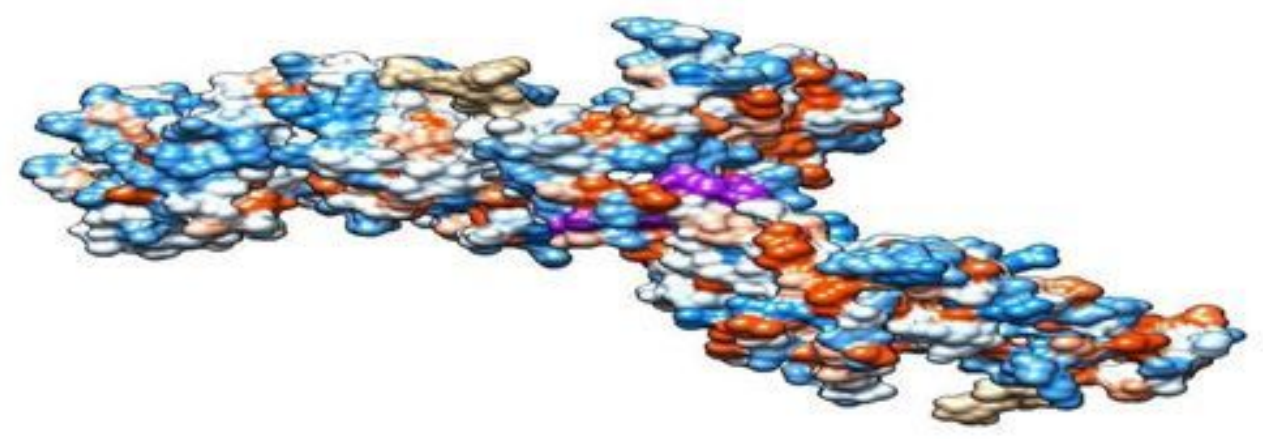

\section{Figure 1}

The position of predicted B -cells peptide GSTVYYPN (purple) on the 3D structure of human Metapneumovirus Fusion Protein
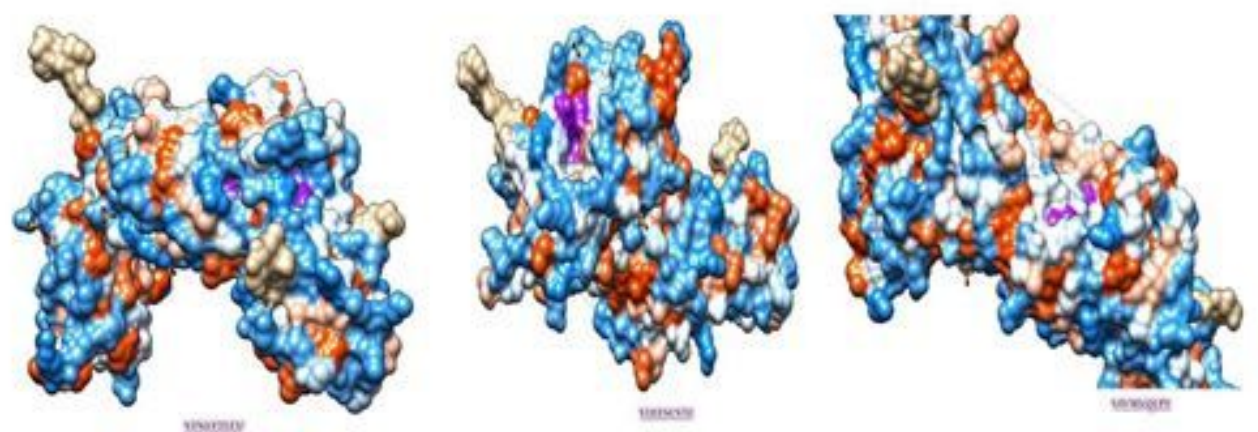

\section{Figure 2}

The position of predicted MHC I peptides (purple) on the 3D structure of human

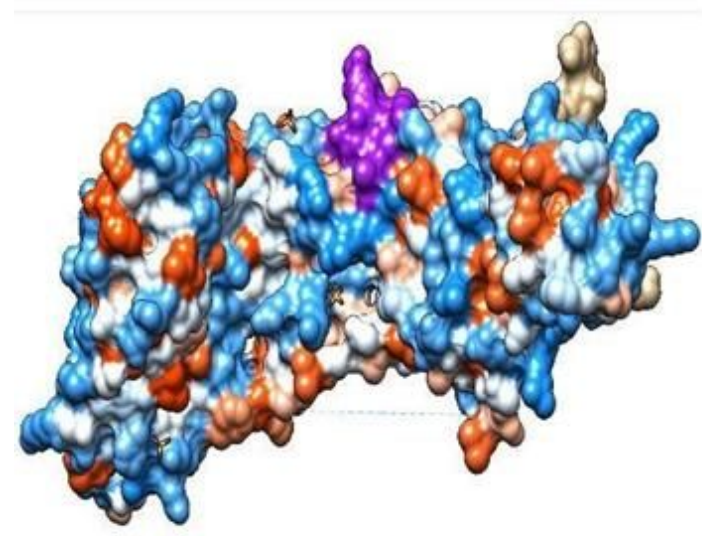

DrMisses

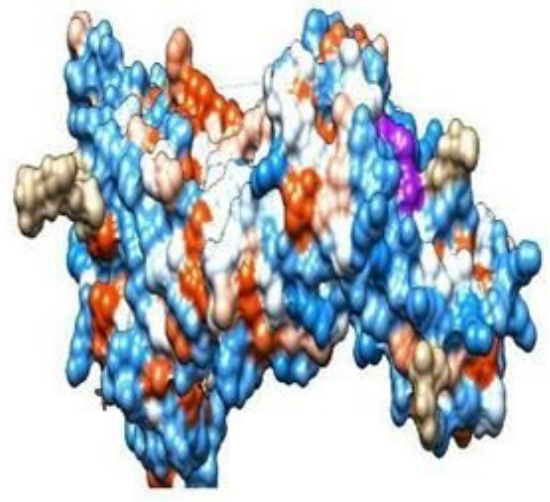

HGMasy

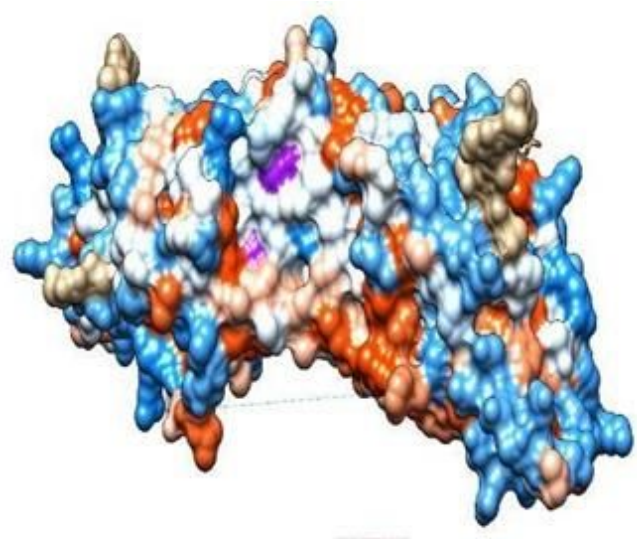

vaseen

\section{Figure 3}

The position of predicted MHC II peptides (purple) on the 3D structure of human Metapneumovirus Fusion Protein 


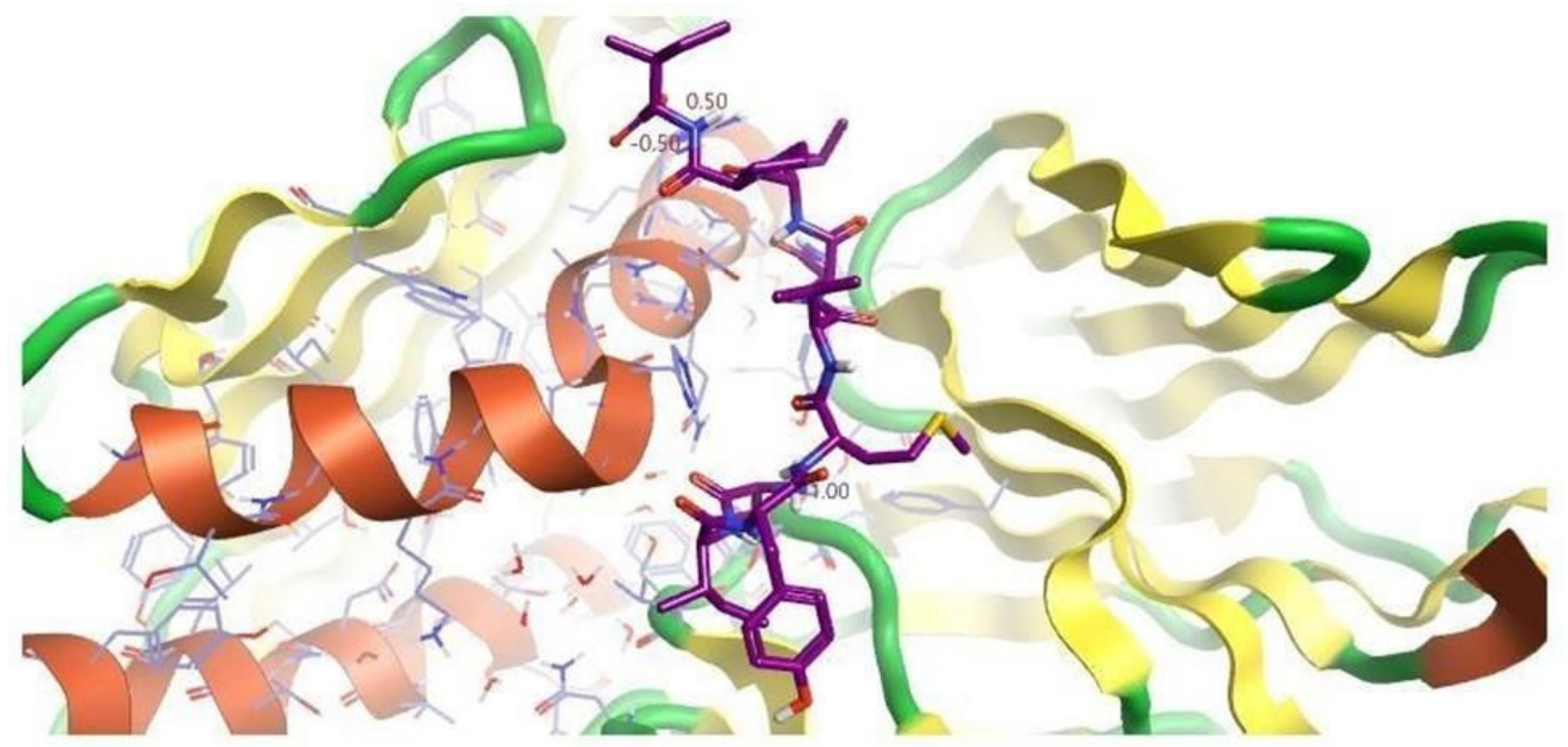

Figure 4

The 3D interaction between the predicted peptide (violet) VIYMVQLPI with MHC IA molecule

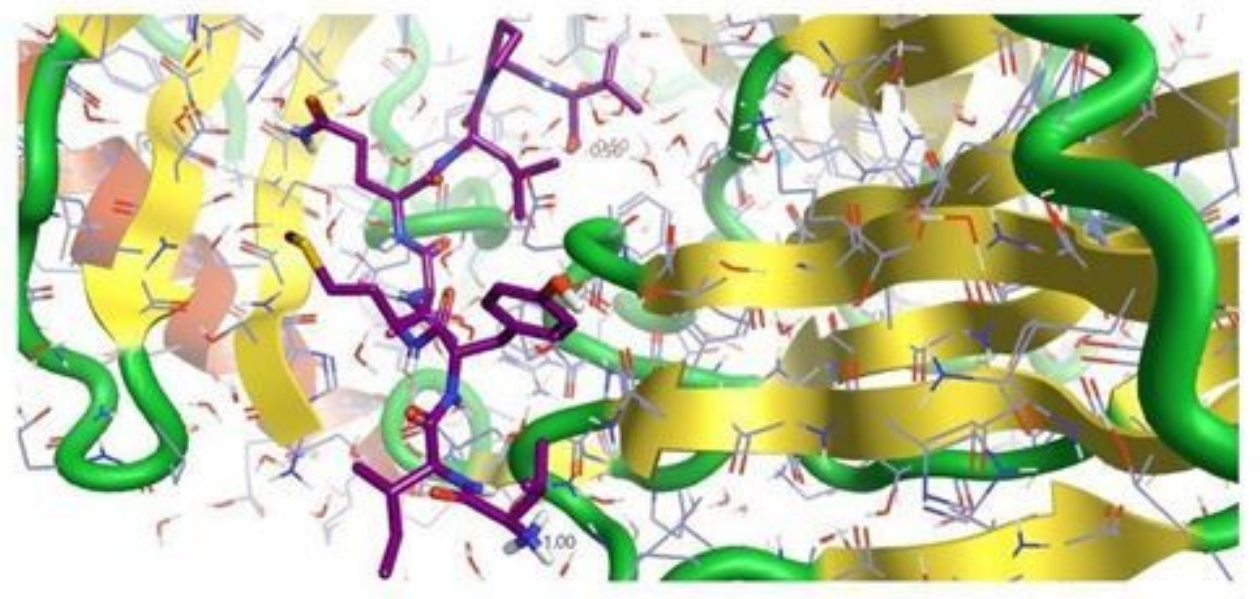

Figure 5

The 3D interaction between the predicted peptide VIYMVQLPI (violet) with the MHC IB molecule 


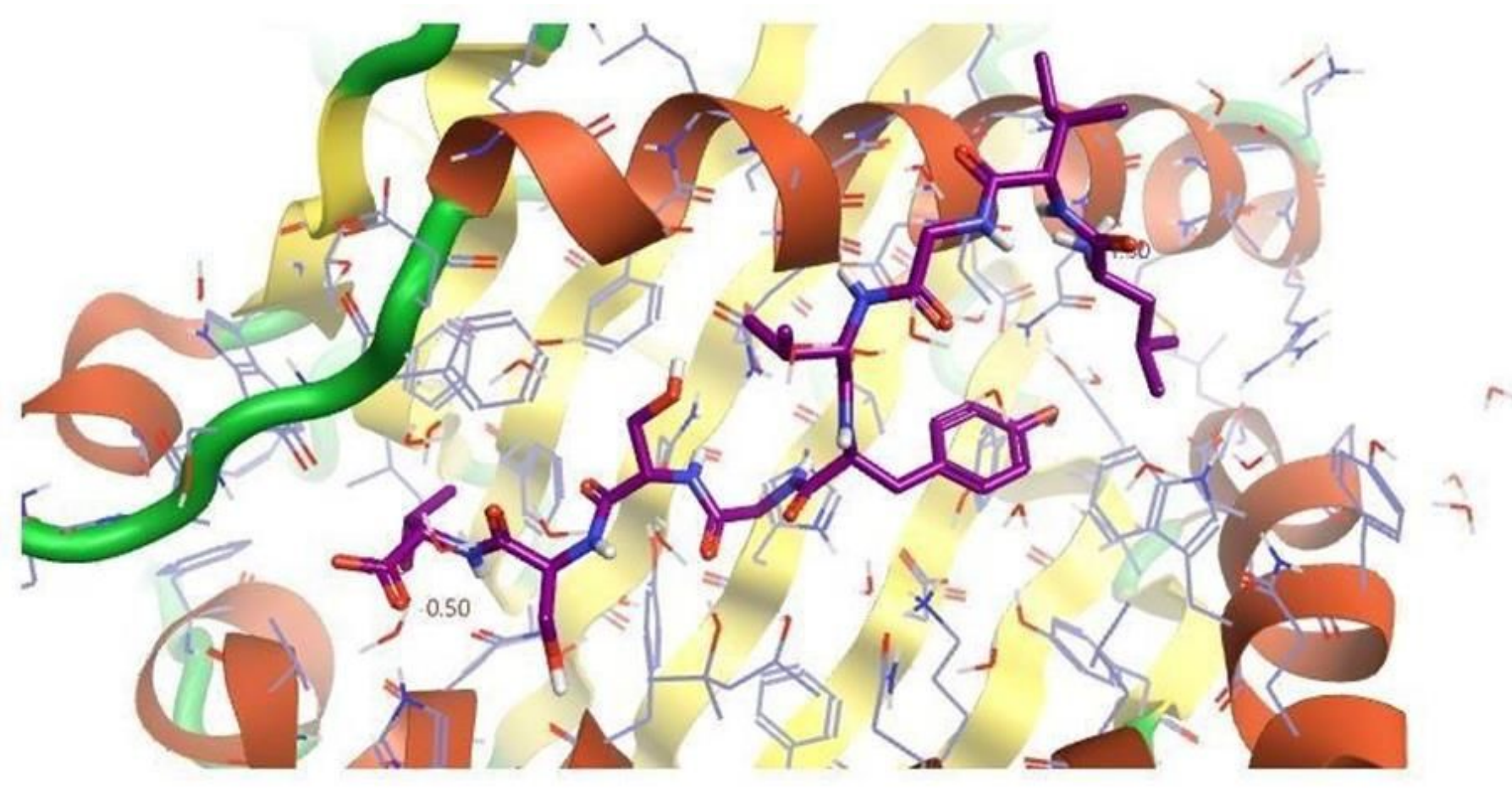

Figure 6

The 3D interaction between the predicted peptide LIGVYGSSV (violet) with the MHC II molecule

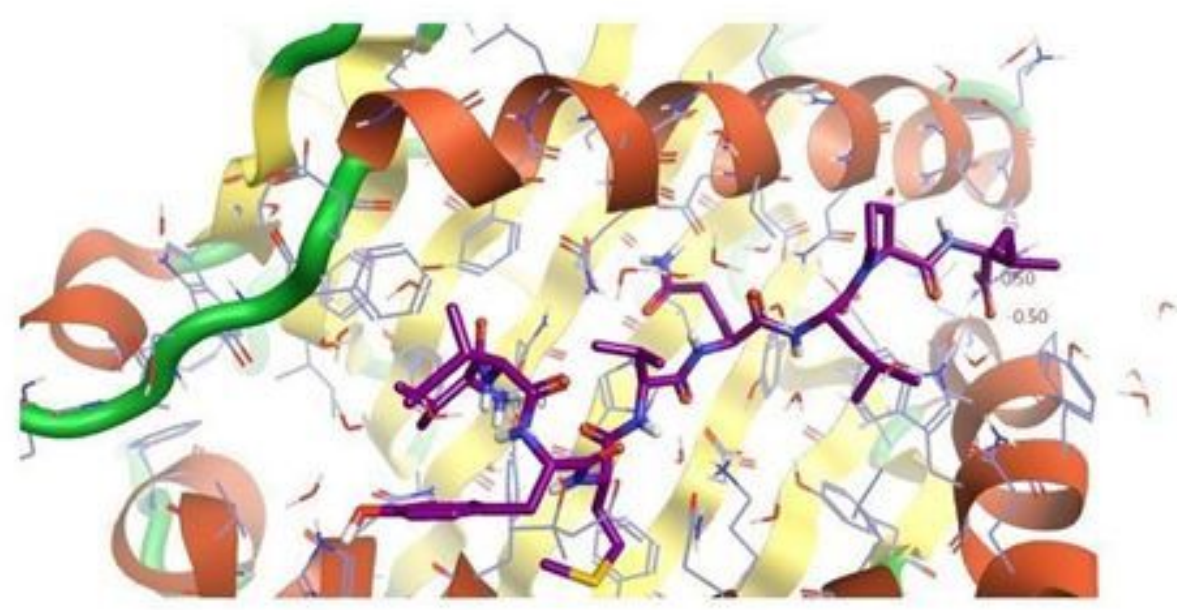

Figure 7

The 3D interaction between the predicted peptide VIYMVQLPI (violet) with MHC II molecule 


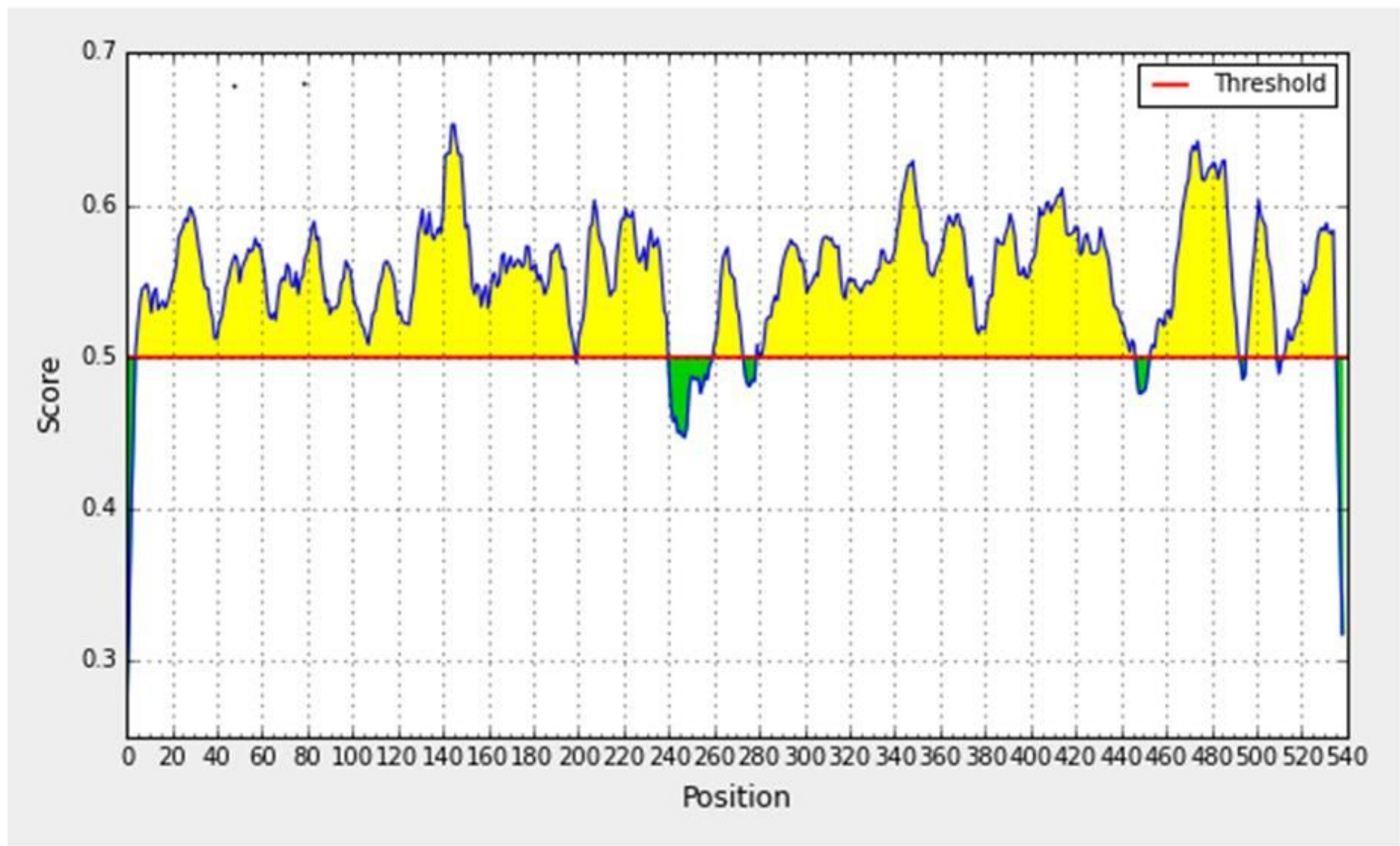

Average: 0.553 Minimum: 0.259 Maximum: 0.653

Figure 8

Bipered linear prediction diagram, where green color referred to predicted peptides 


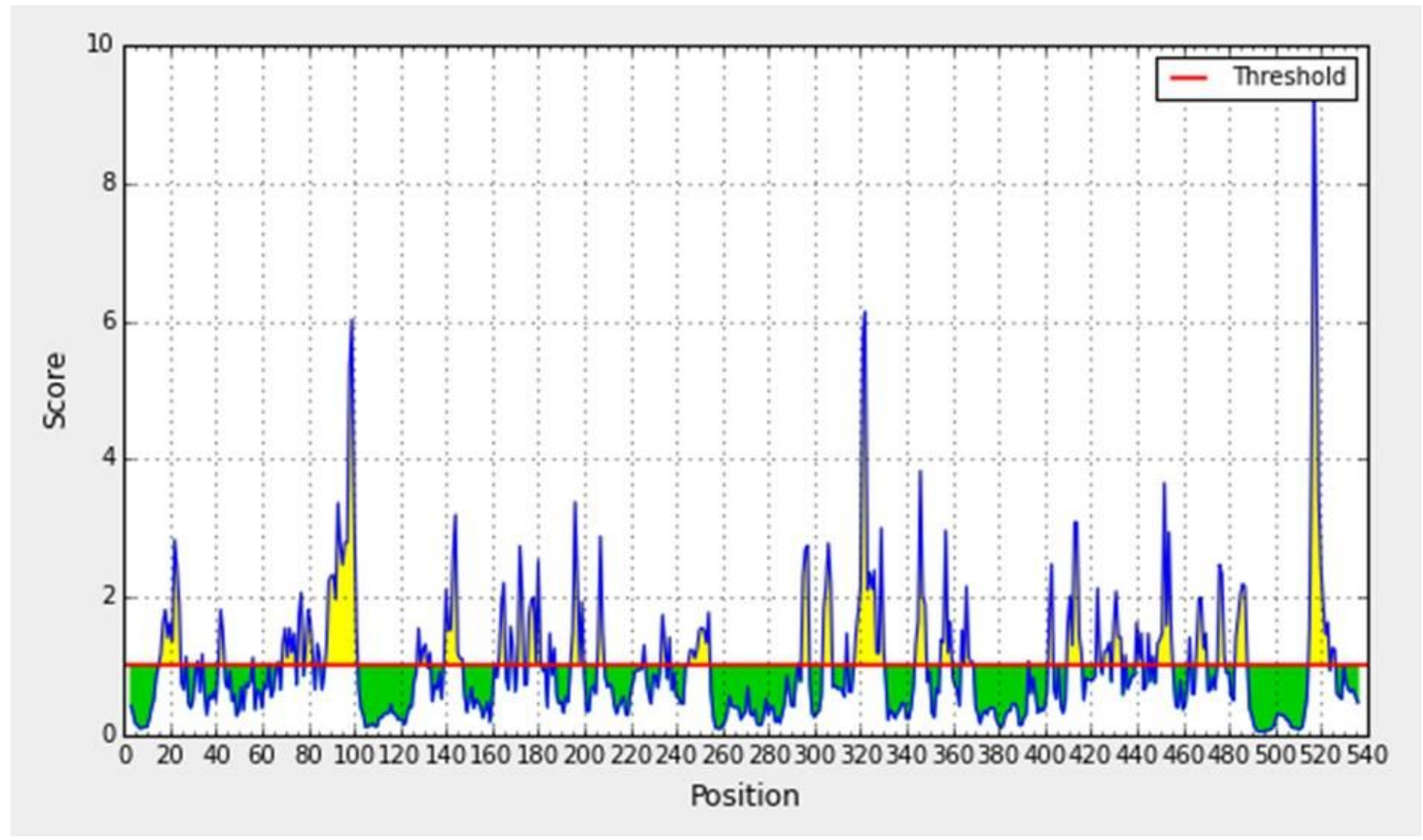

Figure 9

Emini Surface Accessibility Prediction Results, where green color referred to predicted peptides. 


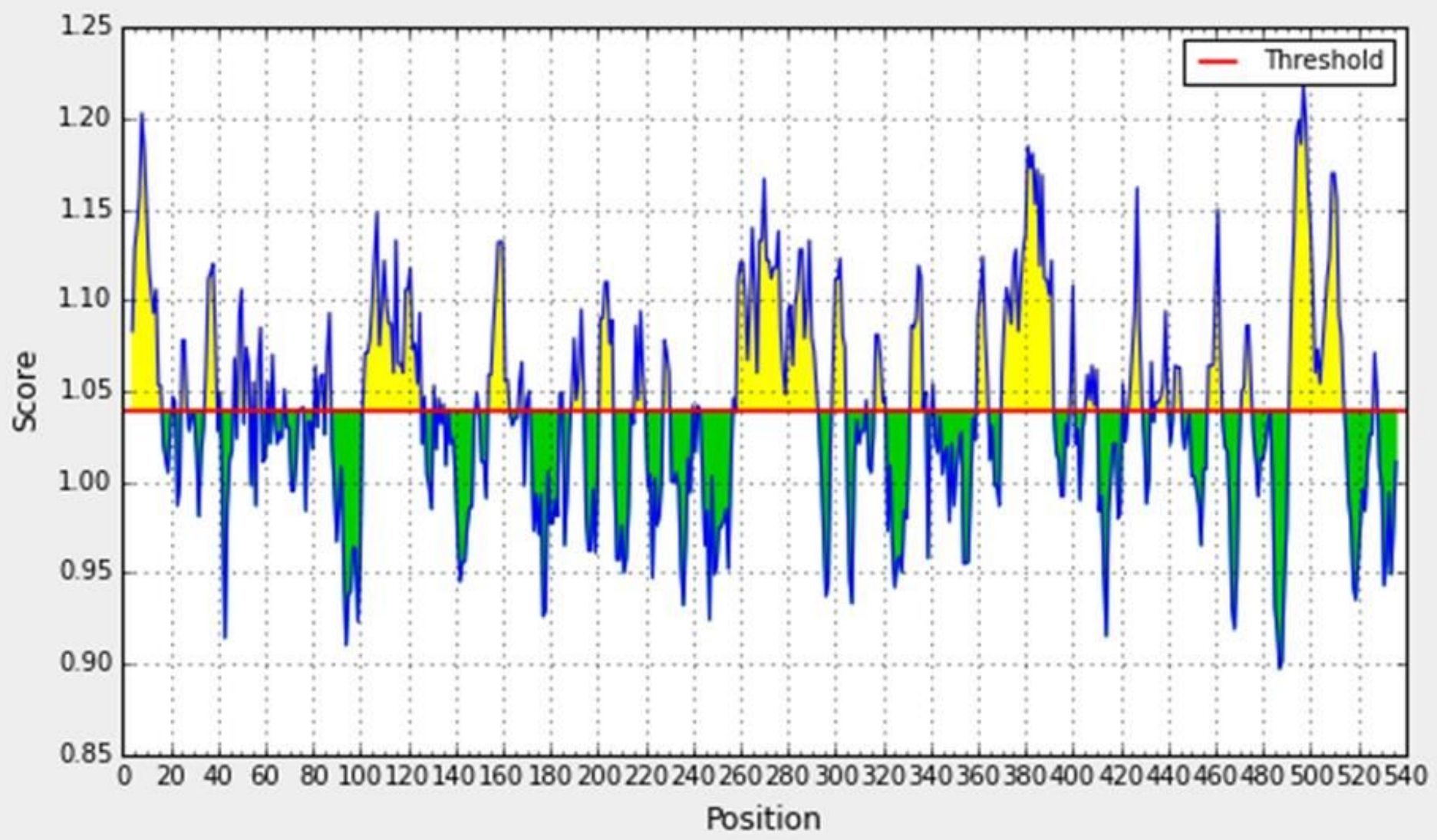

Figure 10

Kolaskar \& Tongaonkar Antigenicity test result, where green color referred to predicted peptides

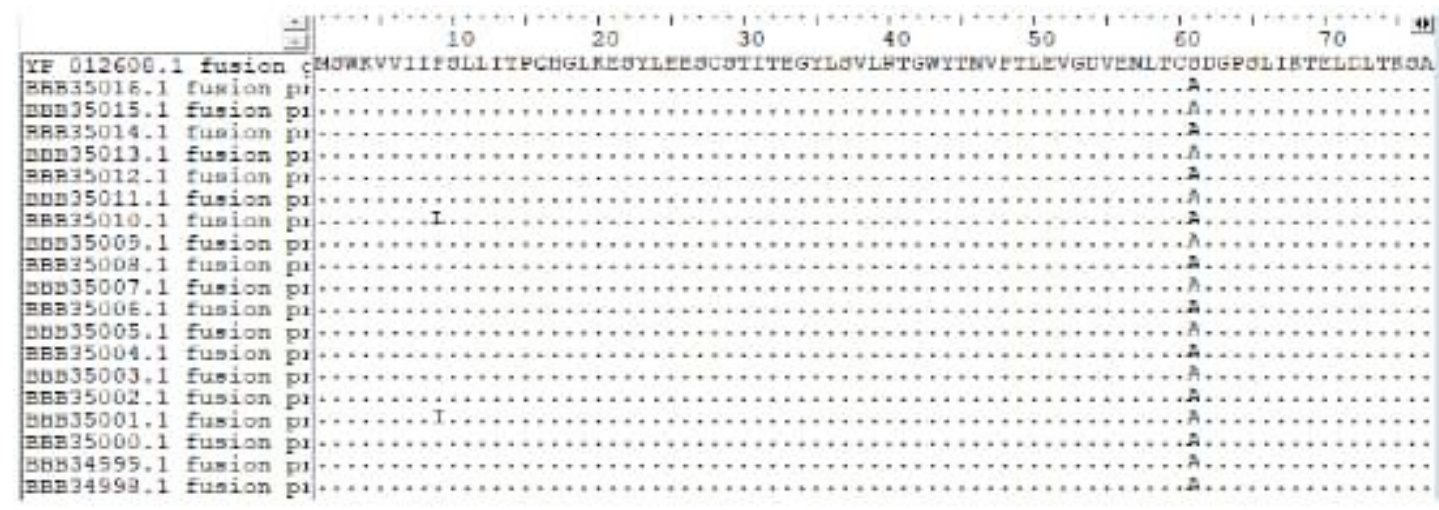

Figure 11

The result of the ready BioEdite alignment server for HMNP the partial part of the whole sequence.

\section{Supplementary Files}

This is a list of supplementary files associated with this preprint. Click to download.

- Table3.docx 